\title{
Model of Construction Waste Management Using AMOS-SEM for Indonesian Infrastructure Projects
}

\author{
Elizar $^{1,{ }^{*}}$, Suripin ${ }^{2}$, and Mochamad Agung Wibowo ${ }^{2}$ \\ ${ }^{1}$ Engineering Department, Islamic University of Riau, Pekanbaru, 28284, Indonesia \\ ${ }^{2}$ Engineering Department, Diponegoro University, Semarang, 50275, Indonesia
}

\begin{abstract}
Construction waste is being produced by the infrastructure project. Thus, waste minimization is an important area to implementation of the construction waste management in Indonesia. This paper aims to build model of construction waste management and to determine the significantly of factors that can improved construction waste management for Indonesian infrastructure projects. This study identified 20 factors to improve the construction waste management that grouped into 5 groups, they are policy, asset, technology, human resources and knowledge. Methods of research carried out by site observation and discussion with contractors using questionnaire instrument and focusing to contractors engaged in various type infrastructure projects in Indonesia with amount of 383 respondents. The 5 groups of factors were developed into AMOSSEM model to determine significant level in contributing to construction waste management. Data was analyzed uses the Structural Equation Modeling (SEM) techniques with the aid of Analysis of Moment Structures (AMOS) statistical package to overcome these factors, where a family of statistical models that seek to explain the relationships of covariant among multiple variables were formulated by combining a measurement model with structural model into a statistical test. The model will be recommandation to improve construction waste management for Indonesian infrastructure projects future.
\end{abstract}

\section{Introduction}

The construction industry is one of the important in Indonesia because it provides various infrastructure that serves to support various economic activities of the community. Crucial issues facing the Indonesian nation today is the condition of inadequate infrastructure, both quantity and quality. One of the infrastructure that describes this phenomenon is the road infrastructure [1]. These condition depend on the project management system implemented by the contractor and owner of the infrastructure project. The low commitment of the contractor to the contract resulted in a significant delay. Such facts can be identified as construction waste that has an impact of the cost, time and quality

*elizar2011@gmail.com 
of the infrastructure project management system. In the activities of many construction projects are faced with various problems such as low productivity [2], lack of supply capacity [3], low technology innovation [4]. These problems either directly or indirectly result in significant waste in the construction process [5]. Base on the chain of analytical processes of waste management and waste control business, the identification of seven factors of success criteria for waste management, they are waste management regulations, low waste technology, waste management system, awareness of waste management, reducing design change, development of science waste and waste management practise [6]. The concept of waste management and identification methods helps the management team to control and manage waste on construction project [7]. In this paper discusses construction waste management model which aims as a recommendation to reduce waste waste during the process of implementation of infrastructure projects. The relationship of component witch to support of construction waste management are analysed using Analysis of Moment Structures (AMOS) based on the concept of Structural Equation Model (SEM). Conclusions based on the model results are presented. Last, this paper presents other significant construction waste management of research that could potentially benefit from AMOS-SEM modelling techniques.

\subsection{Construction Waste Management}

Construction waste management is effort to minimize construction waste on the construction phase from the project feasibility until the project maintenance. This can be achieved by educating stakeholder and the benefits of implementing construction waste management system for effectiveness of waste reduction [8]. Success factor of construction waste management system can be done by among others; waste management regulation, waste management system, awareness of waste management, low-waste building technologies, fewer design changes, research and development [6]. Approaches that consider the identification of the application of methodologies depend on the type of problem at the stage of the process. Knowledge management methodology is a approach using the quality and quantity of available information. The methodology divides knowledge about a process into five main classes which contribute in different levels of waste minimization; crucial knowledge is the one responsible for the initial description of the process, prior knowledge refers to information obtained previously about objects, actors and actions needed to perform, subordinate knowledge is the one without which, the performance of the process might be unsatisfactory or unsuccessful, contextual knowledge refer to the contribution of any situation affecting the perception of the actors or performance of the objects and causal knowledge is identified in the form of relationships between object, actors and variables [9]. The factors of commitment of the parties involved in the implementation of waste management system [10]. Likewise with adequate working environment, reliable cooperation, practice and health workforce can improve the construction waste management system [11]. The success of construction waste management is also influence by regulatory factors, systems, technology, and awareness on waste management [6]. Technology identification and right technology is also influence on construction waste management [7]. Furthermore, development of construction waste management needed to build of contractor commitment [12], on the other side, Waste management plan has the most important effects on the assessment waste of equipment, labour and time [13]. With good communication and documentation system, construction waste can be identified and reduced [14]. 


\subsection{Structural Equation Model (SEM)}

Structural Equation Model (SEM) is a statistical technique to test and estimate causal relationships by integrating factor and path analysis. SEM can examine a series of dependence relationships simultaneously. It is particularly useful in testing theories that contain multiple equations involving dependence relationships. SEM is the development of General Linier Model (GLM) with multiple regression as main part. SEM is more reliable, illustrative and robust than regression techniques when modelling interaction, nonlinearity, measurement errors, error term correlations and correlation among multiple independent variables [15]. Although SEM models can be tested in different ways, all structural equation model are distinguished by three characteristics [16]:

1. Estimation of multiple and interrelated dependence relationships

2. An ability to represent unobserved concept in these relationships and account for measurement.

3. Defining a model to explain the entire set of relationships Structural Equation Modelling can examine a series of dependence relationships simultaneously.

SEM provides a useful way in which to determine whether observed data concur with a priori hypotheses on the structure of incentives [17]. Figure 1 illustrates a simple SEM model incorporating both the measurement and structural relationships of two constructs with four indicators each.



(a) Correlational Relationship

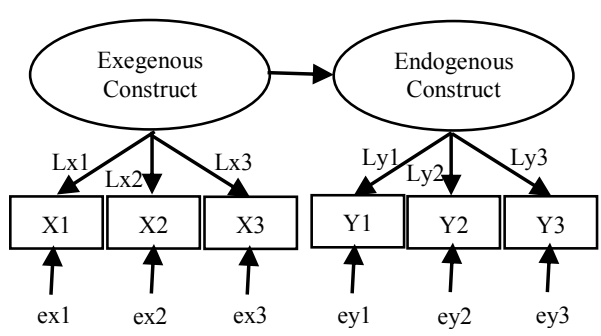

(b) Dependence Relationship

Fig. 1. Visual representation measurement and structural model relationships in a Simple SEM Model [16]

In Figure 1a, there is a correlational relationship between the two constructs, indicated by the curved arrow. The indicators (four on each construct) are labeled $X 1$ to $X 8$. Figure $1 \mathrm{~b}$ depicts a dependence relationship between the exogenous and endogenous construct [16].

\subsection{Analysis of Moment Structures (AMOS)}

Analysis of Moment Structures (AMOS) is statistical package to overcome these issues, where a family of statistical models that seek to explain the relationships among multiple variables were formulated by combining a measurement model with structural model into a simultaneous statistical test [17]. AMOS is included in Covariance Based Equation Modelling (CB-SEM) analysis. Commonly, CB-SEM aims to estimate the theoretical structural model and examine the clausal relationship between constructs and measure model feasibility and confirm according to empirical data [18]. The model can be said fit if it meets three criteria of standard measurement. The criteria in the Goodness of Fit (GOF) measurement are absolute fit measures, incremental fit indices and parsimony fit indices, Table 1 shows the GOF characteristic [16]. 
Table 1. Model fit measurement indices [16]

\begin{tabular}{|c|c|c|}
\hline Characteristic & Good of Fit Measures & Cut-off Values Based \\
\hline \multirow{3}{*}{ Absolute fit indices } & CMIN/DF & $<5$ \\
\cline { 2 - 3 } & GFI & 0 to 1 \\
\cline { 2 - 3 } & RMSEA & 0.05 to 0.08 \\
\hline \multirow{3}{*}{ Incremental fit indices } & AGFI & 0 to 1 \\
\cline { 2 - 3 } & TLI & 0 to 1 \\
\cline { 2 - 3 } & NFI & 0 to 1 \\
\hline \multirow{3}{*}{ Parsimonious fit indices } & PRATIO & 0 to 1 \\
\cline { 2 - 3 } & PNFI & 0 to 1 \\
\cline { 2 - 3 } & PGFI & 0 to 1 \\
\hline
\end{tabular}

Table 1 shows the model fit measurement indices. Absolute fit indices is a direct measures of how well the model specified by researcher reproduces the observed data and analysed by CMIN/DF is the value of chi square divided by degree of freedom, Goodness of Fit Index (GFI) was an early attempt to produce a fit statistic that was less, Root Mean Square Error of Approximation (RMSEA) one of the most widely used measures that attempts to correct for the tendency of the chi square. Incremental fit indices, the most common baseline model is referred to as a null model and analysed by Adjusted Goodness of Fit (AGFI) is the development of a GFI to the degree of freedom ratio for a proposed model with a degree of freedom for the null model to as a null model, Tucker Lewis Index (TLI) is actually a comparison of the normed chi-square values for the null and specified model, Normed Fit Index (NFI) is comparison between model proposed with null model. Parsimonious fit indices is improved either by a better fit or by a simpler model and analysed by parsimony ratio (PRATIO) is calculated as the ratio of degrees of freedom used by a model to the total degrees of freedom available, Parsimony Normed Fit Index (PNFI) is a modification of NFI, Parsimonious Goodness of Fit Index (PGFI) is a modification of GFI [16].

\section{Research Method}

The research method was done by observations and interviews with the contractors who involved in infrastructure project using the questionnaires. Variables and indicators was collected based on observation and literature review from selected study have been done in past nearly 10 years. Although these studies are not definitely similar about the purpose and method of survey, the comparison is useful for understanding the problems of construction management in infrastructure project due to waste problems in selected studies as shown in Table 2. 
Table 2. Comparison between selected studies

\begin{tabular}{|c|c|c|c|c|c|}
\hline \multirow{2}{*}{ Study } & \multicolumn{5}{|c|}{ Construction Waste Management Variables } \\
\cline { 2 - 6 } & 1 & 2 & 3 & 4 & 5 \\
\hline $\begin{array}{c}\text { Indonesia, } \\
\text { this study } \\
{[19]}\end{array}$ & Policy & Asset & Technology & $\begin{array}{c}\text { Human } \\
\text { Resources }\end{array}$ & Knowledge \\
\hline Vietnam [14] & $\begin{array}{c}\text { waste } \\
\text { management } \\
\text { ability }\end{array}$ & $\begin{array}{c}\text { conduct } \\
\text { training }\end{array}$ & $\begin{array}{c}\text { audit and } \\
\text { provide }\end{array}$ & $\begin{array}{c}\text { sequence } \\
\text { activities }\end{array}$ & $\begin{array}{c}\text { punishmen } \\
\text { ts }\end{array}$ \\
\hline China [11] & $\begin{array}{c}\text { physical } \\
\text { working } \\
\text { environment }\end{array}$ & operative & safety & practitioners & $\begin{array}{c}\text { long-term } \\
\text { health }\end{array}$ \\
\hline China [6] & $\begin{array}{c}\text { waste } \\
\text { management } \\
\text { system }\end{array}$ & $\begin{array}{c}\text { low waste } \\
\text { technology }\end{array}$ & $\begin{array}{c}\text { fewer design } \\
\text { change }\end{array}$ & research & practice \\
\hline Korea [10] & $\begin{array}{c}\text { manpower } \\
\text { material and } \\
\text { equipment }\end{array}$ & $\begin{array}{c}\text { construction } \\
\text { method }\end{array}$ & $\begin{array}{c}\text { management } \\
\text { practice }\end{array}$ & $\begin{array}{c}\text { industry } \\
\text { policy }\end{array}$ \\
\hline UK [9] & $\begin{array}{c}\text { crucial } \\
\text { knowledge }\end{array}$ & $\begin{array}{c}\text { prior } \\
\text { knowledge }\end{array}$ & $\begin{array}{c}\text { subordinate } \\
\text { knowledge }\end{array}$ & $\begin{array}{c}\text { contextual } \\
\text { knowledge }\end{array}$ & $\begin{array}{c}\text { causal } \\
\text { knowledge }\end{array}$ \\
\hline
\end{tabular}

Table 2 shows the comparison construction waste management variables. In this study, each variables have indicator that to support construction waste management. The indicator is shown as in Table 3.

Table 3. Variables and indicators of construction waste management

\begin{tabular}{|c|l|}
\hline \multicolumn{1}{|c|}{ Variable } & \multicolumn{1}{|c|}{ Indicator } \\
\hline Policy & construction waste management rule \\
\hline & construction waste management certificate \\
\hline & construction waste management incentive \\
\hline & reward and sanctions \\
\hline Asset & construction waste management operational \\
\hline & HR asset : creative, initiative, innovative \\
\hline & Social asset : care of environment \\
\hline Technology & Equipment asset : management system \\
\hline & Construction waste management information \\
\hline & Data base of waste construction \\
\hline & Low waste of construction method \\
\hline Human Resource & equipment innovative \\
\hline & Degree of study \\
\hline & Skill Certificate \\
\hline & Commitment \\
\hline Knowledge & Analysis capability \\
\hline & waste construction of knowledge \\
\hline & Construction waste management of knowledge \\
\hline & Reduce, reuse and recycling of knowledge \\
\hline & Improve skill of knowledge \\
\hline
\end{tabular}


Table 3 shows type of variable and indicator for construction waste management which uses in questionnaire. The respondents are requested to select using liker scale of option between 1 to 5 terms of relative importance. A score of "1" represents "not influence" to improve construction waste management whereas a score of " 5 " represents "very large influence" to support of construction waste management. The data was collected from 383 respondents and estimated the correlation model constructed through the Analysis of Moment Structures (AMOS) version 22.0 for windows.

\section{Result and Discussion}

This study create analyses measurement of construction waste management model aims to determine the effect of relationships between indicators. The model of construction waste management serves as a recommendation for improving the infrastructures project in Indonesia. Construction waste management model have five components, they are policy, asset, technology, human resources and knowledge. Correlation between components as shown in Figure 2.

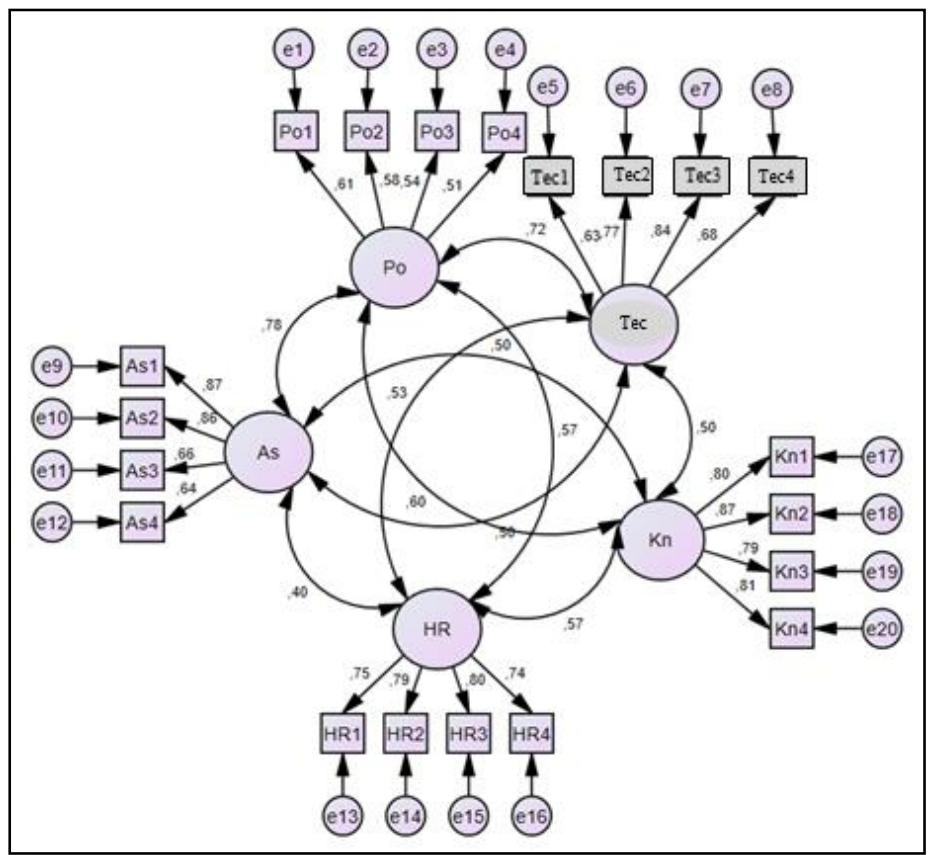

Fig. 2. Corrélation between indicators of construction waste management model

Base on figure 2 shows corrélation between indicators, the result is corrélation of policy and asset with path coefficient value of 0.78 ; policy and technology with path coefficient value of 0.72 ; policy and knowledge with path coefficient value of 0.60 ; policy and human resources with path coefficient value 0.57 ; asset and technology with path coefficient value of 0.50 ; asset and human resources with path coefficient value of 0.40 ; asset and knowledge with path coefficient value of 0.50 ; technology and knowledge with path coefficient value of 0.50 , human resources and knowledge with path coefficient value 0.57 . The coefficient result show value is equal to greater 0.05 . It means having a significant correlation except the correlation between asset and human resources is below 0.4. The result of the Goodness of Fit characteristic as shows in Table 4. 
Table 4. Measurement model fit indices

\begin{tabular}{|c|c|c|c|}
\hline Measurement & Value & Cut-off values based & Conclusion \\
\hline CMIN/DF & 2.524 & $<5$ & Fit \\
\hline GFI & 0.911 & 0 to 1 & Fit \\
\hline RMSEA & 0.063 & 0.05 to 0.08 & Fit \\
\hline AGFI & 0.883 & 0 to 1 & Fit \\
\hline TLI & 0.921 & 0 to 1 & Fit \\
\hline NFI & 0.895 & 0 to 1 & Fit \\
\hline PRATIO & 0.842 & 0 to 1 & Fit \\
\hline PNFI & 0.754 & 0 to 1 & Fit \\
\hline PCFI & 0.786 & 0 to 1 & \\
\hline
\end{tabular}

In Table 4 shows the results analysis of construction waste management model base on the Goodness of Fit characteristic is fit.

According to [6] that the success of construction waste management is also influenced by regulatory factors, management system, technology, awareness on waste management, waste management research and practice. So it can be said that construction waste management is an important part in strategy to reduce construction waste both physical and non-physical.

The result of this study can be said in accordance with [6] study but need to be strengthened with assets that support construction waste management system. So that with construction waste management model can give the final result of efficient infrastructure project.

\section{Conclusion}

The result show that outcome the model is fit with CMIN/DF value of 2.524, GFI value of 0.911 , AGFI value of 0.833 , TLI value of 0.921 , CFI value of 0.933 and RMSEA value of 0.063 . The significant level to contributing construction waste management from 5 groups were covariant corrélation of policy and asset with path coefficient value of 0.78 , policy and technology with path coefficient value of 0.72 , policy and knowledge with path coefficient value of 0.60 , policy and human resources with path coefficient value of 0.57 , asset and technology with path coefficient value of 0.50 , asset and human resources with path coefficient value of 0.40 , asset and knowledge with path coefficient value of 0.50 , technology and human resources with path coefficient value of 0.53 , technology and knowledge with path coefficient value of 0.50 , human resources and knowledge with path coefficient value of 0.57 . The results of the model show that relationship between policy and asset has the highest correlation to support of construction waste management system. The model will be useful to improve construction waste management for minimize construction waste on infrastructures projects in Indonesia.

\section{Aknowledgements}

The authors are very grateful to the Program of Overseas Seminar Aid, Directorate General of Strengthening for Research and Development, The Ministry of Research, Technology, and Higher Education Republic of Indonesia. The authors are also grateful to Islamic University of Riau and the respondents of various infrastructure projects in Indonesia for their help with the quetionnaire. 


\section{References}

1. M. Abduh, Konstruksi Indonesia (Kementerian Pekerjaan Umum, 2012)

2. C. Ho, P.M. Nguyen, M.H. Shu, Information and Management Science, 18, 403-426 (2007)

3. T.V. Luu, S.Y. Kim, H.L. Cao and Y.M. Park, Construction Management and Economics, 26, 373-386 (2008)

4. T.N.Q. Nguyen, P.A. Neck and T.H. Nguyen, International Business Research Journal, 2, 3-16 (2009)

5. H.D. Khanh and S.Y. Kim, Construction Management Journal, 18, 867-874 (2014)

6. W. Lu and H. Yuan, Resources Conservation and Recycling, 55, 201-208 (2010)

7. J. Yang and D. Mitchell, The Construction, Building and Real Estate Research Conference of the Royal Institution of Chartered Surveyor (2010)

8. O.F. Kofoworola and S.H. Gheewala, Waste Management Journal, 29, 731-738 (2009)

9. A.P.R. Cardoba, P.N. Sharratt and J.A.A. Sanchez, Process Safety and Environment Protection Journal, 86, 375-388 (2008)

10. H.S. Cha, J. Kim and J.Y. Han, Construction Engineering and Management, 135, 647656 (2009)

11. H. Yuan, Waste Management Journal, 32, 1218-1228 (2012)

12. T. Ninmann, Waste Management: Plan for it Before, During and After Construction (2011)

13. O.J. Oladiran, Architectural Engineering and Design Management, 5, 165-176 (2009)

14. F.Y.Y. Ling and D.S.A. Nguyen, Built Environment Project and Asset Journal, 3, 141156 (2013)

15. Jogiyanto, Konsep dan Aplikasi Structural Equation Modeling Berbasis Varian Dalam Penelitian Bisnis (2011)

16. Jr.J.F. Hair, W.C. Black, B.J. Babin and R.E. Anderson, Multivariate Data Analysis (2014)

17. U.K.J. Mudalige, J.M.M. Udugama and S.M.M. Ikram, Applied Statistics, 13, 15-37 (2012)

18. H. Latan, Aplikasi Analisis Data Statistik Untuk Ilmu Sosial Sains dengan IBM SPSS (2014)

19. Elizar, M.A, Wibowo and P. Koestalam, Procedia Engineering, 125, 46-52 (2015) 